\title{
Classification of medically important clostridia using restriction endonuclease site differences of PCR-amplified 16S rDNA
}

\author{
Volker Gurtler, ${ }^{*}$ Vicki A. Wilson and Barrie C. Mayall \\ Department of Microbiology, Repatriation General Hospital Heidelberg, Heidelberg West 3081, Victoria, Australia
}

(Received 11 April 1991; revised 15 July 1991; accepted 5 August 1991)

\begin{abstract}
Restriction maps were constructed of enzymically amplified 16S rRNA genes (rDNA) isolated from eight Clostridium species. Using maximum parsimony, a dendrogram was constructed from these and published 16S rRNA sequence data. Two distinct clusters were identified: cluster I contained $C$. difficile, $C$. sordelli, and $C$. bifermentans, and showed 30 of 35 restriction sites in common; cluster II contained C. tetani, $C$. perfringens $C$. sporogenes and $C$. botulinum $C$ and $G$, and showed 20 of 35 restriction sites in common. Further analysis of cluster I organisms revealed that of five $\mathrm{HpaII}$ fragments, two were found in equal amounts in all organisms, one was found in varying amounts in all organisms, and two were found, in varying amounts, only in $C$. sordelli and C. bifermentans. $C$. sordelli-specific and $C$. bifermentans-specific $H$ pall fragments were demonstrated by Southern hybridization of rDNA. One $\mathrm{HpaII}$ site within the rDNA was present on most alleles in $\mathrm{C}$. bifermentans, present on a minority of alleles in $C$. sordelli and absent in $C$. difficile. This suggested that there were two 16S rRNA alleles with different sequences present within each of the genomes of $C$. bifermentans and $C$. sordelli.
\end{abstract}

\section{Introduction}

Within the genus Clostridium, there is a wide diversity in metabolic activity, nutritional requirements and $\mathrm{mol} \%$ $\mathrm{G}+\mathrm{C}$ (Cato et al., 1986). This often makes classification using phenotypic characteristics inaccurate, and in some species reliance is placed on testing for species- and typespecific toxins (Hatheway, 1990). Molecular biology techniques may thus be useful for classification within the genus. The eight Clostridium species studied in this paper fall into homology groups I and II as defined by the rRNA sequence homology experiments of Johnson \& Francis (1975).

To allow more rapid diagnosis of infections caused by Clostridium species, the development of a rapid diagnostic technique based on species-specific DNA sequences is desirable. The $16 \mathrm{~S}$ rRNA gene represents a suitable genomic candidate, enabling analysis of species-specific differences by restriction enzyme analysis. While the sequences of some regions of the 16S rRNA gene are homologous in all bacteria (Neefs et al., 1990), other regions of this gene show considerable variation. However, 16S rRNA sequence analysis has so far been reported for only a few medically important Clostridium species (Weisburg et al., 1989; Tanner et al., 1981, 1982). Here we report the use of restriction enzymes to demonstrate species differences in the sequence of amplified 16S rRNA genes from eight species of Clostridium using the polymerase chain reaction.

\section{Methods}

Bacterial strains. The type strains obtained from the American Type Culture Collection (Rockville, Md.) were C. difficile ATCC 9689, C. bifermentans ATCC 638, C. sordelli ATCC 9714 and CDC-14337, C. sporogenes ATCC $11437, C$. botulinum Type C ATCC C17849, C. botulinum Type G ATCC G27322, C. perfringens ATCC 13124 and E3624. Other strains used were $C$. perfringens JIR 4 (from Dr J. I. Rood, Monash University, Clayton, Australia), C. difficile (630) (from Dr H. Hachler, University of Zurich, Switzerland), C. tetani 045, C. bifermentans AM 360 and AM312 (from Dr R. Wilkinson, University of Melbourne, Australia), together with clinical isolates of $C$. difficile (016, 020, and 023), C. sordelli (008) and C. tetani (041) (from the Repatriation General Hospital, Heidelberg, Australia).

Cultivation. All strains were tested using the Rapid ANA II System (Innovative Diagnostics Systems, Ga., USA) and by GLC (Sutter $e t$ al., 1985). Purified stocks were stored in cooked-meat broth at room temperature and in glycerol broth at $-20^{\circ} \mathrm{C}$. All clostridia were grown in brain heart infusion broth (BHI: GIBCO).

DNA isolation. Genomic DNA was isolated from all clostridia by the protocol of Barbour \& Garon (1987), with some modifications. Bacteria were grown in $\mathrm{BHI}$ and all volumes were reduced by a factor of ten. The cell walls were disrupted by the method of Hachler et al. (1987) except that lysozyme was added to a final concentration of $10 \mathrm{mg} \mathrm{ml}^{-1}$. After one phenol/chloroform extraction, the DNA was ethanol-precipitated (Sambrook et al., 1989), dried in a Speedvac concentrator and redissolved in 100-200 $\mu \mathrm{l}$ TE (10 $\mu \mathrm{M}$-Tris, pH 8.0, 1 mM-EDTA). 
DNA amplification. For DNA amplifications the protocol of Saiki et al. (1988) was followed, with some modifications. The mixtures of $100 \mu \mathrm{l}$ contained $0.5 \mu \mathrm{g}$ genomic DNA (in $50 \mathrm{mM}-\mathrm{KCl}, 10 \mathrm{~mm}$-Tris, $\mathrm{pH} 8.3,0.01 \%$ gelatin, $0.1 \%$ Triton-X-100, $5 \mathrm{~mm}-\mathrm{MgCl}_{2}$ ), primer (at $0.5 \mu \mathrm{M}$ ), the four dNTPs (at $200 \mu \mathrm{M}$ ) and 1 unit of Taq polymerase (Boehringer). Mineral oil $(100 \mu \mathrm{l})$ was then added, and the mixture subjected to 40 cycles of the following incubations: $1 \mathrm{~min}$ at $95^{\circ} \mathrm{C}$, $1 \mathrm{~min}$ at $50{ }^{\circ} \mathrm{C}$ and $2-3 \mathrm{~min}$ at $70^{\circ} \mathrm{C}$. The reaction was terminated by the addition of $10 \mu \mathrm{l}$ of loading buffer $[0.25 \%$ bromophenol blue, $0.25 \%$ xylene cyanol FF, $40 \%(\mathrm{w} / \mathrm{v})$ sucrose] and the mixture was stored at $4{ }^{\circ} \mathrm{C}$. The efficiency of the reaction was estimated by analysing $10 \mu \mathrm{l}$ of the mixture on $1 \%(\mathrm{w} / \mathrm{v})$ 'AR' agarose minigels. The primers used were designed from the conserved regions of the 16S rRNA sequence of Escherichia coli (Brosius et al., 1978) and allowed amplification of the (R015-R1408) and (R907-R1408) regions, using the numbering system of Lane $e t$ al. (1985). The forward primers were (R015-R027) GATCCTGGCTCAG and (R907-R926) AAACTCAAATGAATTGACGG and the reverse primer was (R1391-R1408) GACGGGCGGTGTGTACAA.

Preparative agarose gel electrophoresis. After initial analysis of the PCR products, three reactions were pooled and separated on $4 \%(w / v)$ low-gelling-temperature agarose, or $1 \%(w / v)$ 'AR' agarose minigels. The predominant bands of 1.4 or $0.5 \mathrm{~kb}$ were cut from the gel and the DNA was purified using a Gene Clean kit following the manufacturer's instructions (Bio 101).

Restriction enzyme analysis. Purified PCR products (R015-R1408) and (R907-R1408) were digested singly or doubly with combinations of 10-15 units of $A l u \mathrm{I}, M s p \mathrm{I}, H a e \mathrm{III}, H p a \mathrm{II}, H i n d \mathrm{III}, R s a \mathrm{I}$ and CfoI, as instructed by the manufacturer (Boehringer). Genomic DNA was digested with 30 units of $\mathrm{HpaII}$ and/or HaeIII. The restriction fragments were resolved on $4 \%(w / v)$ low-gelling-temperature agarose gels.

Pulsed-field gel electrophoresis. Agarose blocks containing DNA from Clostridium species were prepared by the method of Smith \& Cantor (1987) with some modifications. Bacteria were grown in $2 \mathrm{ml}$ BHI, washed once in $0.2 \mathrm{ml} \mathrm{SE}(75 \mathrm{~mm}-\mathrm{NaCl}, 25 \mathrm{~mm}$-EDTA, $\mathrm{pH} 7 \cdot 4)$ and resuspended in $0.2 \mathrm{ml} \mathrm{SE}$ with $2 \mathrm{mg}$ lysozyme $\mathrm{ml}^{-1}$. Agarose blocks were prepared, placed in SE with $2 \mathrm{mg}$ lysozyme $\mathrm{ml}^{-1}$ for $1 \mathrm{~h} \mathrm{at} 37^{\circ} \mathrm{C}$, incubated overnight in lysis solution [ $1 \mathrm{mg}$ proteinase $\mathrm{K} \mathrm{ml}^{-1}, 1 \%(\mathrm{w} / \mathrm{v})$ $\mathrm{N}$-lauroylsarcosine, $0.5 \mathrm{M}$-EDTA, pH 9.5], and washed six times in TE and three times in restriction buffer. To each half block was added a $10 \mu \mathrm{l}$ solution containing restriction buffer, $2 \mathrm{~mm}$-spermidine, $0.2 \mathrm{mg}$ BSA ml-1 and 40 units $S m a I$. The DNA fragments were separated on $1.2 \%(w / v)$ 'AR' agarose using a Pulsaphor II unit (Pharmacia) at $10^{\circ} \mathrm{C}$ with a voltage of $170 \mathrm{~V}$ and pulse times of $80 \mathrm{~s}$ for $16 \mathrm{~h}, 100 \mathrm{~s}$ for $5 \mathrm{~h}$, and $120 \mathrm{~s}$ for $3 \mathrm{~h}$. Molecular mass markers were concatemers of $\lambda \mathrm{cI} 857$ Sam7.

Data analysis. The restriction enzyme site data were analysed by three methods. (1) The presence or absence of restriction enzyme sites was scored by either a 1 or 0 respectively. The resulting data matrix was analysed by maximum parsimony using the program PAUP (Swofford, 1985). (2) Common restriction sites were analysed by calculating ' $D$ ' values (Nei \& Li, 1979; Vilgalys \& Hester, 1990) for each of the six restriction enzymes. The average of the six individual distance matrices ( $D$ values) was used to construct a dendrogram using the NJTree program (version 2.0) which is based on the neighbour-joining method (Saitou \& Nei, 1987). (3) The amount of each Hpall restriction fragment relative to the total PCR product (R015-R1408) was quantified by scanning the Polaroid negative of the ethidium-bromidestained gel using a Helena Laboratories laser densitometer.

Southern hybridization. DNA fragments separated by electrophoresis were transferred to nylon membranes (Sambrook et al., 1989). The digoxigenin labelling and detection system was used according to instructions (Boehringer), with some modifications. The PCR product (R015-R1408) from C. bifermentans $360(1.2 \mu \mathrm{g})$ was labelled with digoxigenin by incubation in a total volume of $100 \mu \mathrm{l}$, with all reagent concentrations as stated, for $16 \mathrm{~h}$ at $37^{\circ} \mathrm{C}$. After prehybridization, the filter was hybridized for $16 \mathrm{~h}$ in $20 \mathrm{ml}$ of solution containing $0.5 \mu \mathrm{g}$ digoxigenin-labelled DNA ml-1. The filter was washed and the hybridized DNA detected colorimetrically. The filter was photographed while wet, using Polaroid type 55 film.

\section{Results and Discussion}

\section{Phylogeny}

The restriction maps of region (R015-R1408) for eight Clostridium species are shown in Table 1. The eight species were arranged on the basis of restriction site similarities into cluster I ( $C$. difficile, $C$. bifermentans, $C$. sordelli) and cluster II (C. tetani, $C$. perfringens, $C$. sporogenes, $C$. botulinum $\mathrm{C}+\mathrm{G})$. Five restriction site differences occurred within cluster I [at $\operatorname{AluI}(205,455)$, HpaII (215) and HindIII $(425,625)]$ compared with 15 within cluster II [at $A l u \mathrm{I}(85,205,245,455,855,995$, 1305), HaeIII (285, 325, 445, 925), HpaII (1135, 1305), $H$ indIII (85) and $C f o I(380)]$. There were no differences in the three RsaI sites within cluster II or the six RsaI, three $C f o$ I and four HaeIII sites within cluster I. There were no intra-species site differences detected with all enzymes. Examples of the fragment differences within and between clusters are shown in Fig. 1.

When the data shown in Table 1 were analysed by maximum parsimony, four parsimonious trees were obtained. The consensus dendogram of these four trees is shown in Fig. 2. Between the four trees the branching order was fixed, except for Bacillus subtilis, C. sporogenes, C. botulinum $\mathrm{C}$ and $\mathrm{G}$ (shown by trichotomies). In all possible trees, Mycoplasma capricolum, $C$. ramosum, and C. sticklandii were positioned between clusters I and II. The reference species ( $C$. ramosum, $C$. innocuum, $C$. sticklandii, $M$. capricolum and $E$. coli) were well separated from clusters I and II. A similar dendogram was obtained when the data were analysed by the neighbourjoining method (not shown).

The rRNA homology studies of Johnson \& Francis (1975) demonstrated that $C$. tetani, $C$. sordelli and $C$. bifermentans were in group II; group I was divided into ten subgroups with $C$. perfringens in IC, $C$. sporogenes in IF, C. botulinum $\mathrm{C}$ in IH and C. botulinum $\mathrm{G}$ in IK ; group III contained $C$. ramosum and $C$. sticklandii while $C$. innocuum was in an homology group distinct from I, II and III. These results correlate well with the present study, except that $C$. tetani fell into cluster II and no differences were found between $C$. sporogenes and $C$. botulinum $\mathrm{C}$. It has been shown by $16 \mathrm{~S}$ rRNA sequence analysis that the Mycoplasma cluster is in close proximity 
Table 1. Restriction maps of the region (R015-R1408) of the $16 S$ rRNA gene from eight Clostridium species

Single and double restriction enzyme digests of PCR products (R015-R1408) and (R907-R 1408) were used to construct the maps. An average of three single digests were done for each product and each enzyme. The restriction fragment lengths for the single digests were totalled, giving an average value for region (R015-R1408) of $1371 \pm 7 \mathrm{bp}$ (mean $\pm \operatorname{SEM}: n=139$ ). The site numbering is analogous to that of the $E$. coli $16 \mathrm{~S}$ rRNA sequence (Brosius et al., 1978). The presence of a site is denoted by + and the absence of a site is denoted by - . The site denoted by $+/-$ is site $Q$ in Fig. 4.

\begin{tabular}{|c|c|c|c|c|c|c|c|c|c|}
\hline \multirow[b]{2}{*}{ Enzyme } & \multirow[b]{2}{*}{ Site } & \multicolumn{3}{|c|}{ Cluster I } & \multicolumn{5}{|c|}{ Cluster II } \\
\hline & & C. difficile & C. bifermentans & C. sordelli & C. tetani & C. perfringens & C. sporogenes & C. botulinum C & C. botulinum $\mathrm{G}$ \\
\hline \multirow[t]{11}{*}{ AluI } & 85 & - & - & - & - & - & + & + & + \\
\hline & 205 & - & + & + & + & - & - & - & - \\
\hline & 245 & + & + & + & - & + & + & + & + \\
\hline & 455 & - & + & + & - & + & - & - & - \\
\hline & 615 & + & + & + & - & - & - & - & - \\
\hline & 855 & + & + & + & + & - & - & - & - \\
\hline & 995 & + & + & + & + & - & - & - & - \\
\hline & 1045 & + & + & + & + & + & + & + & + \\
\hline & 1135 & + & + & + & - & - & - & - & - \\
\hline & 1305 & - & - & - & + & - & - & - & + \\
\hline & 1345 & + & + & + & + & + & + & + & + \\
\hline \multirow[t]{4}{*}{ HaeIII } & 285 & - & - & - & - & + & - & - & - \\
\hline & 325 & + & + & + & - & + & + & + & + \\
\hline & 445 & + & + & + & - & - & - & - & + \\
\hline & 925 & - & - & - & - & - & + & + & + \\
\hline \multirow{6}{*}{ HpaII } & 215 & - & $+/(-)$ & $(+) /-$ & - & - & - & - & - \\
\hline & 495 & + & + & + & - & - & - & - & - \\
\hline & 545 & + & + & + & + & + & + & + & + \\
\hline & 605 & - & - & - & + & + & + & + & + \\
\hline & 1135 & - & - & - & + & - & - & - & + \\
\hline & 1305 & - & - & - & - & - & - & - & + \\
\hline \multirow[t]{4}{*}{ HindIII } & 85 & - & - & - & - & - & + & + & - \\
\hline & 425 & - & - & + & - & - & - & - & - \\
\hline & 625 & - & + & + & - & - & - & - & - \\
\hline & 975 & + & + & + & - & - & - & - & - \\
\hline \multirow[t]{7}{*}{$R s a \mathrm{I}$} & 115 & + & + & + & - & - & - & - & - \\
\hline & 370 & + & + & + & - & - & - & - & - \\
\hline & 475 & - & - & - & + & + & + & + & + \\
\hline & 530 & + & + & + & - & - & - & - & - \\
\hline & 895 & + & + & + & + & + & + & + & + \\
\hline & 1260 & + & + & + & + & + & + & + & + \\
\hline & 1315 & + & + & + & - & - & - & - & - \\
\hline \multirow[t]{3}{*}{ CfoI } & 245 & - & - & - & + & + & + & + & + \\
\hline & 380 & - & - & - & - & - & + & + & + \\
\hline & 1100 & + & + & + & + & + & + & + & + \\
\hline
\end{tabular}

to the clostridia (Weisburg et al., 1989). Further studies with additional Clostridium species are required to determine the precise location of $\boldsymbol{M}$. capricolum between clusters I and II.

The finding that $C$. botulinum $\mathrm{G}$ is genetically distinct from $C$. sporogenes and other $C$. botulinum types is consistent with previous biochemical studies (Hatheway, 1990). Although the lack of urease production by $C$. bifermentans is the main criterion for differentiating it from urease-producing $C$. sordelli (Brooks \& Epps, 1958), urease-negative strains of $C$. sordelli have been reported (Nakamura et al., 1976). However, in the present study C. bifermentans 312 was urease-positive, yet there were no intra-species restriction site differences. Thus, the reliance of urease-production to differentiate between $C$. sordelli and $C$. bifermentans may be questionable.

The novel approach described can be used in rapid identification of eight Clostridium species of relevance in the clinical laboratory. The limitation of this method in defining taxonomic relationships is that only $10-15 \%$ of the 16S rRNA gene was analysed. However, the results were mainly consistent with previous biochemical and molecular studies and the approach used was rapid and easy to perform.

\section{Species-specific $r R N A$ alleles}

The number of $16 \mathrm{~S}$ rRNA alleles was determined as seven in $E$. coli (Kiss et al., 1977) and eight in B. subtilis 


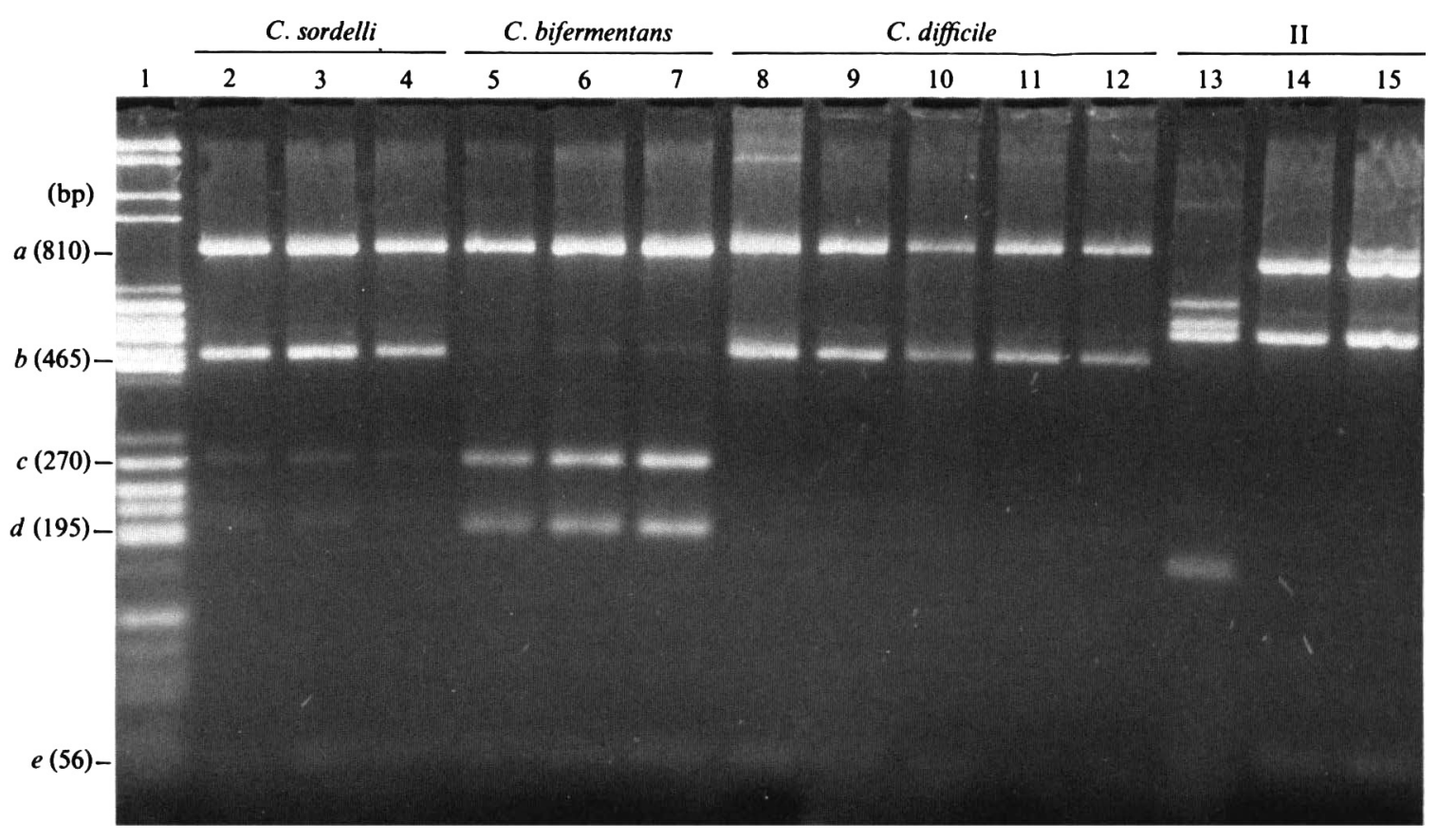

Fig. 1. Electrophoresis of HpaII digests of PCR product (R015-R 1408) from Clostridium species and strains. Lanes: 1, HaeIII-digested pBR322 DNA and (BglI plus HinfI)-digested pBR328 DNA; 2, C. sordelli $9714 ; 3$, C. sordelli $14337 ; 4$, C. sordelli $008 ; 5, C$. bifermentans $312 ; 6, C$. bifermentans $360 ; 7$, C. bifermentans $638 ; 8, C$. difficile $630 ; 9$, . difficile $016 ; 10, C$. difficile $020 ; 11, C$. difficile $023 ; 12$, C. difficile $9689 ; 13, C$. botulinum G G27322; 14, C. botulinum C C17849; 15, C. sporogenes 11437 . The letters $a-e$ refer to Hpall restriction fragments. The sizes of these fragments (error $<5 \%$ ) were determined from $5-9$ experiments for cluster I strains and $2-4$ for cluster II strains.

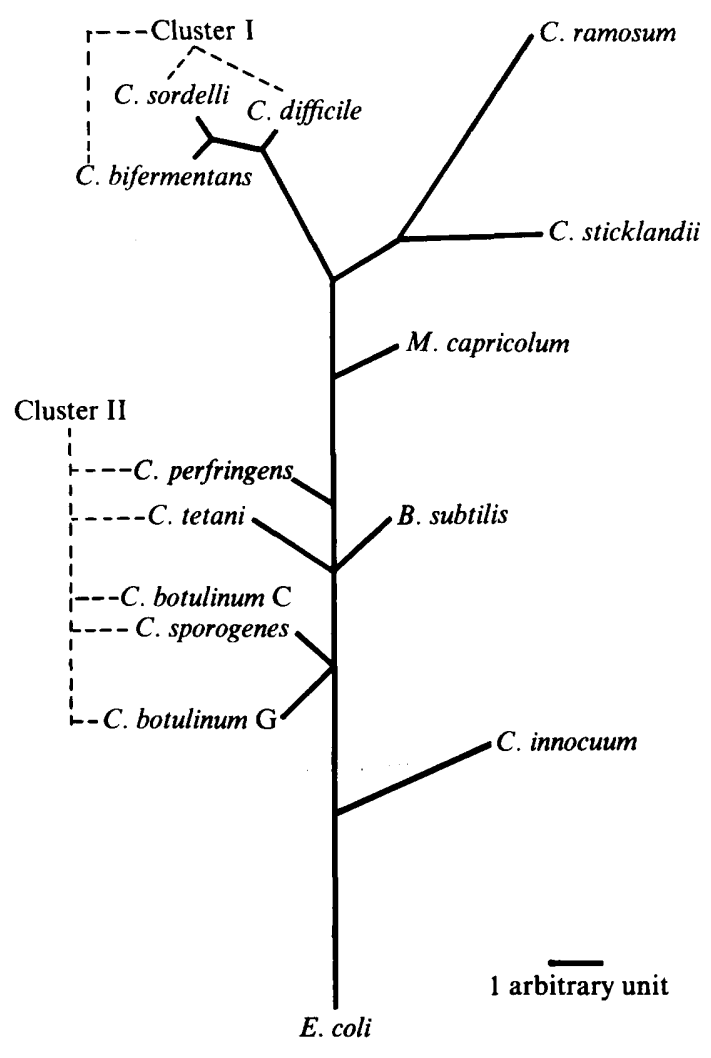

(Moran \& Bott, 1979). In the present study, eight 16S rRNA alleles were detected in $C$. difficile, and ten alleles in $C$. sordelli, when $S m a$ I genomic digests were analysed by pulsed-field electrophoresis and Southern hybridization (not shown).

An analysis of the HpaII sites within region (R015$\mathrm{R} 1408$ ) was undertaken to determine if there was sequence variation between 16S rRNA alleles of cluster I species. Methylation of $\mathrm{HpalI}$ sites did not contribute to restriction site differences since genomic DNA from cluster I digested with $M s p$ I or HpaII gave identical 16S rRNA hybridization patterns (not shown). Genomic DNA digested with $M s p I$ gave identical intra-species hybridization patterns within cluster I (not shown).

Fig. 1 shows differences in the amount of each $\mathrm{HpaII}$ fragment generated from the three cluster I species. These differences were quantified by laser densitometry

Fig. 2. A dendrogram constructed by maximum parsimony, showing the genetic relationships of the Clostridium species and reference strains. A data matrix was constructed using the restriction site data in Table 1. The corresponding information for the same enzymes was deduced from published 16S rRNA sequences from $C$. innocuum, C. sticklandii, C. ramosum, B. subtilis (Neefs et al., 1990), M. capricolum (Lim \& Sears, 1989), and E. coli (Brosius et al., 1978). 




Fig. 3. Hybridization of 16S rRNA genes to genomic DNA and PCR product (R015-R1408). Lanes: 1, HpaII digest of PCR product (R015-R1408); 2, HpaII digest of genomic DNA; 3, HaeIII digest of PCR product (R015-R1408); 4, HaellI digest of genomic DNA; and 5, HaeIII plus HpaII digest of genomic DNA. The DNA was isolated from C. sordelli 14337 (lanes 1, 3, 4, 5), C. sordelli 9714 (lane 2), C. bifermentans 360 (lanes 1-5), and C. difficile 630 (lanes 1-5). Lane M contains 150 ng photodigoxigenin-labelled (BglI plus HinfI)digested pBR328. The letters $b_{1}, d_{1}$ and $d_{2}$ refer to genomic HpaII fragments; $y_{1}$ and $z_{1}$ refer to genomic HaeIII fragments; $x-z$ refer to HaelII fragments of PCR product (R015-R1408) and (a-e) are as defined in Fig. 1. The size of each genomic fragment was determined from three separate Southern hybridization experiments.

and revealed no differences in the relative amounts of fragments $a$ and $e$ but significant differences in amounts of fragments $b, c$, and $d[(35 \%, 3 \%$ and $4 \%$ for $C$. sordelli) compared to $(2 \%, 24 \%$ and $22 \%$ for C. bifermentans $)$ compared to $(46 \%, 0 \%$ and $0 \%$ for $C$. difficile $)$. These differences could be explained by the occurrence of a variable $H p a$ II site which was not found on all $16 \mathrm{~S}$ rRNA alleles in cluster I species.

To confirm the presence of a variable HpaII site in cluster I, species-specific $H$ paII fragments were sought. When DNA was digested with HpaII (Fig. 3), $b$ and $d$ were present only within PCR product (R015-R1408), $b_{1}$ was present only in genomic DNA, $d_{1}$ was present only in genomic DNA from $C$. bifermentans, $d_{2}$ was present only in genomic DNA from $C$. sordelli and $a, c$ and $e$ were present in genomic DNA and PCR product (R015R1408). When DNA was digested with HaeIII (Fig. 3), $y$ was detected only within PCR product (R015-R1408), $y_{1}$ and $z_{1}$ were detected only in total DNA, and $x$ and $z$ were present in genomic DNA and PCR product (R015R1408). The HpaII fragment $d_{1}$ was not digested by $H a e I I I$. The HpaII fragments $b_{1}, c$ and $d_{2}$ were digested by HaeIII, resulting in the appearance of $z_{1}$. Fragment $z_{1}$ was more intense in $C$. bifermentans than in $C$. sordelli.

The distribution of $\mathrm{HpaII}$ restriction fragments within cluster $\mathrm{I}$ is summarized in Fig. 4. Allele A contained $b$ and $b_{1}$, and was predominant in $C$. sordelli. Allele B contained $c, d$ and $z_{1}$, and was predominant in $C$. bifermentans. The location of $C$. sordelli-specific $d_{2}$ and C. bifermentans-specific $d_{1}$ on allele B was confirmed when HaeIII digested $d_{2}$ but not $d_{1}$. Only allele A was present in $C$. difficile. Thus, within cluster I, HpaII site $Q$ was absent in $C$. difficile, present on the minority of alleles in $C$. sordelli and present on the majority of alleles in C. bifermentans.

Variation of rRNA restriction fragments from total 


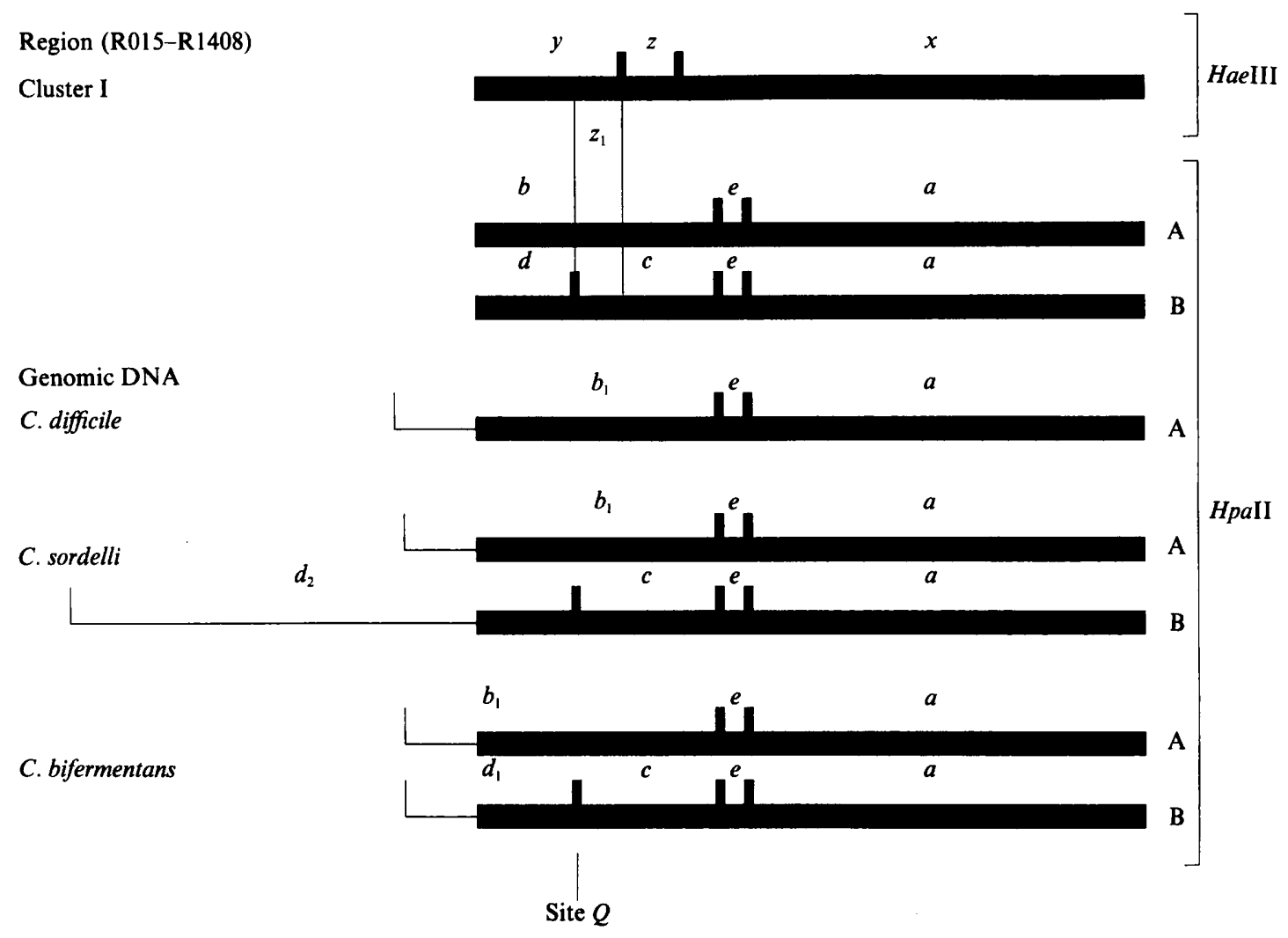

Fig. 4. HpaII restriction map depicting the allelic differences in the $16 \mathrm{~S}$ rRNA genes of $C$. difficile, $C$. bifermentans and $C$. sordelli. The data from Fig. 3 were used to construct the maps shown. Horizontal solid lines represent region (R015-R1408), and horizontal thin lines represent DNA 5 ' of R015. All symbols (defined in Figs 1 and 3) represent regions bounded by restriction sites depicted by a solid vertical line within region (R015-R 1408), and by a thin vertical line 5' of R015. Fragment $z_{1}$ is depicted by two thin vertical lines from one HaeIII and one HpaII site. A and B represent two 16S rRNA alleles.

DNA has been demonstrated between clinical isolates of Providencia stuartii (Owen et al., 1988). However, it has not been demonstrated whether the differences are due to restriction site changes between alleles within a genome. Restriction site differences have been detected between the two 16S rRNA alleles of Halobacterium marismortui (Mevarech et al., 1989). The present study has demonstrated restriction site differences between two alleles present in varying amounts within the genomes of $C$. bifermentans, $C$. sordelli and $C$. difficile. The occurrence of alleles that have different DNA sequences within the genomes of some clostridia may have implications for DNA sequencing and the design of oligonucleotides for PCR.

We thank Drs H. Hachler and R. Wilkinson for helpful discussions. We are grateful to Drs H. Hachler, R. Wilkinson and J. I. Rood for supplying us with bacterial strains. The help of Drs A. Gibbs and $P$. Ladiges with the construction of dendrograms is appreciated. We would like to thank the Department of Veterans' Affairs for permission to publish this paper.

\section{References}

Barbour, A. G. \& Garon, C. F. (1987). Linear plasmids of the bacterium Borrelia burgdorferi have covalently closed ends. Science 237, 409-411.

BROoKs, M. E. \& EPPS, H. B. G. (1958). Taxonomic studies of the genus Clostridium: Clostridium bifermentans and C. sordelli. Journal of General Microbiology 21, 144-155.

Brosius, J., Palmer, M. L., KenNedy, P. J. \& Noller, H. F. (1978). Complete nucleotide sequence of a $16 \mathrm{~S}$ ribosomal RNA gene from Escherichia coli. Proceedings of the National Academy of Sciences of the United States of America 72, 4801-4805.

Cato, E. P., George, W. L. \& Finegold, S. M. (1986). Genus Clostridium Prazmowski 1880, 23 AL. In Bergey's Manual of Systematic Bacteriology, vol. 2, pp. 1141-1200. Edited by P. H. A. Sneath, N. S. Mair, M. E. Sharpe \& J. G. Holt. Baltimore: Williams \& Wilkins.

HACHLER, H., KAYSER, F. H. \& BERGER-BACHI, B. (1987). Homology of a transferable tetracycline resistance determinant of Clostridium difficile with Streptococcus (Enterococcus) faecalis transposon Tn916. Antimicrobial Agents and Chemotherapy 31, 1033-1038.

Hatheway, C. L. (1990). Toxigenic clostridia. Clinical Microbiology Reviews 3, 66-98.

Johnson, J. L. \& Francis, B. S. (1975). Taxonomy of the Clostridia: ribosomal ribonucleic acid homologies among the species. Journal of General Microbiology 88, 229-244. 
Kiss, A., SAin, B. \& Venetianer, P. (1977). The number of rRNA genes in Escherichia coli. FEBS Letters 79, 77-79.

Lane, D. J., Pace, B., Olsen, G. J., Stahl, D. A., Sogin, M. L. \& PACE, N. R. (1985). Rapid determination of $16 \mathrm{~S}$ ribosomal RNA sequences for phylogenetic analyses. Proceedings of the National Academy of Sciences of the United States of America 82, 6955-6959.

LiM, P.-O. \& SEARS, B. B. (1989). 16S rRNA sequence indicates that plant-pathogenic mycoplasma-like organisms are evolutionarily distinct from animal mycoplasmas. Journal of Bacteriology 171, 5901-5906.

Mevarech, M., Hirsch-Twizer, S., Goldman, S., Yakobson, E., EISENBERG, H. \& DENNIS, P. P. (1989). Isolation and characterization of the rRNA gene clusters of Halobacterium marismortui. Journal of Bacteriology 171, 3479-3485.

MORAN, C. P., JR \& BOTT, K. F. (1979). Restriction enzyme analysis of Bacillus subtilis ribosomal ribonucleic acid genes. Journal of Bacteriology 140, 99-105.

Nakamura, S., ShImamura, T. \& Nishida, S. (1976). Urease negative strains of Clostridium sordelli. Canadian Journal of Microbiology 22, 673-676.

Neefs, J.-M., van de Peer, Y., Hendriks, L. \& de Wachter, R. (1990). Compilation of small ribosomal subunit RNA sequences. Nucleic Acids Research 18 (supplement), r2237-r2317.

NeI, M. \& LI, W.-H. (1979). Mathematical model for studying genetic variation in terms of restriction endonucleases. Proceedings of the National Academy of Sciences of the United States of America 76, 5269-5273.

Owen, R. J., Beck, A., Dayal, P. A. \& Dawson, C. (1988). Detection of genomic variation in Providencia stuartii clinical isolates by analysis of DNA restriction fragment length polymorphisms containing rRNA cistrons. Journal of Clinical Microbiology 26, 2161-2166.

Saikı, R. K., Gelfand, D. H., Stoffel, S., Scharf, S. J., Higuchi, R.,
Horn, G. T., Mullis, K. B. \& ERLICH, H. A. (1988). Primer-directed enzymatic amplification of DNA with a thermostable DNA polymerase. Science $239,487-491$.

SaITOU, N. \& NEI, M. (1987). The neighbor-joining method: a new method for reconstructing phylogenetic trees. Molecular Biology and Evolution 4, 406-425.

Sambrook, J., Fritsch, E. F. \& Maniatis, T. (1989). Molecular Cloning: a Laboratory Manual, 2nd edn. Cold Spring Harbor, NY: Cold Spring Harbor Laboratory.

Smith, C. L. \& Cantor, C. R. (1987). Purification, specific fragmentation, and separation of large DNA molecules. Methods in Enzymology 155, 449-467.

Sutter, V. L., Citron, D. M., Edelstein, M. A. C. \& Finegold, S. M. (1985). Wadsworth Anaerobic Bacteriology Manual, 4th edn. Belmont, California: Star Publishing Company.

SWOFFORD, D. L. (1985). Phylogenetic analysis using parsimony (PAUP) version 2.4. University of Illinois.

TANner, R. S., Stackebrandt, E., Fox, G. E. \& Woese, C. R. (1981). A phylogenetic analysis of Acetobacterium woodii, Clostridium barkeri, Clostridium butyricum, Clostridium lituseburense, Eubacterium limosum and Eubacterium tenue. Current Microbiology 5, 35-38.

TANNER, R. S., Stackebrandt, E., Fox, G. E., Gupta, R., Magrum, L. J. \& WOESE, C. R. (1982). A phylogenetic analysis of anaerobic eubacteria capable of synthesizing acetate from carbon dioxide. Current Microbiology 7, 127-132.

Weisburg, W. G., Tully, J. G., Rose, D. L., Petzel, J. P., Oyaizu, H., Yang, D., Mandelco, L., Sechrest, J., Lawrence, T. G., van EtTen, J., Maniloff, J. \& Woese, C. R. (1989). A phylogenetic analysis of the mycoplasmas : basis for their classification. Journal of Bacteriology 171, 6455-6467.

VILGALYS, R. \& HESTER, M. (1990). Rapid genetic identification and mapping of enzymatically amplified ribosomal DNA from several Cryptococcus species. Journal of Bacteriology 172, 4238-4246. 